\title{
Article \\ Phenytoin Inhibits Cell Proliferation through microRNA-196a-5p in Mouse Lip Mesenchymal Cells
}

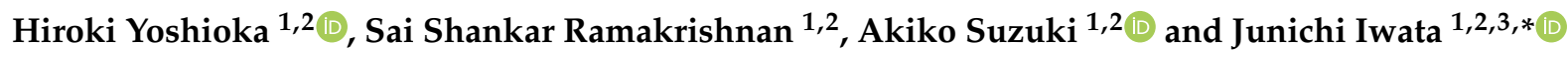 \\ 1 Department of Diagnostic \& Biomedical Sciences, School of Dentistry, The University of Texas Health Science \\ Center at Houston, Houston, TX 77054, USA; Hiroki.Yoshioka@uth.tmc.edu (H.Y.); \\ Sai.Shankar.Ramakrishnan@uth.tmc.edu (S.S.R.); akikosuz925@gmail.com (A.S.) \\ 2 Center for Craniofacial Research, The University of Texas Health Science Center at Houston, Houston, \\ TX 77054, USA \\ 3 MD Anderson Cancer Center UTHealth Graduate School of Biomedical Sciences, Houston, TX 77030, USA \\ * Correspondence: Junichi.Iwata@uth.tmc.edu; Tel.: +1-713-486-2641; Fax: +1-713-486-4416
}

Citation: Yoshioka, H.;

Ramakrishnan, S.S.; Suzuki, A.; Iwata J. Phenytoin Inhibits Cell Proliferation through microRNA-196a-5p in Mouse Lip Mesenchymal Cells. Int. J. Mol. Sci. 2021, 22, 1746. https://doi.org/ $10.3390 /$ jims 22041746

Academic Editor: Imad Kansau

Received: 14 January 2021

Accepted: 5 February 2021

Published: 9 February 2021

Publisher's Note: MDPI stays neutral with regard to jurisdictional claims in published maps and institutional affiliations.

Copyright: () 2021 by the authors. Licensee MDPI, Basel, Switzerland This article is an open access article distributed under the terms and conditions of the Creative Commons Attribution (CC BY) license (https:// creativecommons.org/licenses/by/ $4.0 /)$.

\begin{abstract}
Cleft lip (CL) is one of the most common birth defects. It is caused by either genetic mutations or environmental factors. Recent studies suggest that environmental factors influence the expression of noncoding RNAs [e.g., microRNA (miRNA)], which can regulate the expression of genes crucial for cellular functions. In this study, we examined which miRNAs are associated with CL. Among 10 candidate miRNAs (miR-98-3p, miR-101a-3p, miR-101b-3p, miR-141-3p, miR-144-3p, miR181a-5p, miR-196a-5p, miR-196b-5p, miR-200a-3p, and miR-710) identified through our bioinformatic analysis of CL-associated genes, overexpression of miR-181a-5p, miR-196a-5p, miR-196b-5p, and miR-710 inhibited cell proliferation through suppression of genes associated with CL in cultured mouse embryonic lip mesenchymal cells (MELM cells) and O9-1 cells, a mouse cranial neural crest cell line. In addition, we found that phenytoin, an inducer of CL, decreased cell proliferation through miR-196a-5p induction. Notably, treatment with a specific inhibitor for miR-196a-5p restored cell proliferation through normalization of expression of CL-associated genes in the cells treated with phenytoin. Taken together, our results suggest that phenytoin induces CL through miR-196a-5p induction, which suppresses the expression of CL-associated genes.
\end{abstract}

Keywords: cleft lip; microRNA; craniofacial development; environmental factor; phenytoin; gene regulation

\section{Introduction}

Cleft lip with or without cleft palate $(\mathrm{CL} / \mathrm{P})$ is one of the most common congenital malformations, with a prevalence of 1 in 500 to 1 in 2500 live births worldwide. There are syndromic and nonsyndromic forms of CL/P, often caused by gene mutations, teratogenic exposure, and chromosomal modifications [1-4]. It is currently estimated that approximately $70 \%$ of CL/P cases are nonsyndromic. The etiology of CL/P is thus complex, with multifactorial involvement of genetic and environmental factors along with geographic, racial, and ethnic influences. Previous mouse genetic studies showed that mutations in various genes result in cleft lip (CL), cleft palate, and midfacial cleft. An increasing number of studies suggest that the causative factors for birth defects might be grouped according to shared functions (e.g., cell proliferation, differentiation) and pathways (e.g., growth factor signaling pathways). However, it remains unclear how epigenetic factors regulate CL-associated genes.

Upper lip formation comprises growth and fusion of the facial prominences, including the maxillary process (MP) and the medial and lateral nasal processes (MNP and LNP), which begins on day 26 of gestation in humans and embryonic day (E) 9.5 in mice and is completed by day 48 in humans and E12.5 in mice [5]. Any failure in the development of the MP and MNP leads to CL $[5,6]$. To identify the mechanism of CL, mouse models 
have been extensively used, since mouse lip formation and their molecular mechanisms are similar to those of humans.

MicroRNAs (miRNAs) comprise approximately 20-22 nucleotide RNAs that play a crucial role in development and disease through the regulation of genes at the posttranscriptional level [7-9]. DICER and DROSHA are key enzymes that generate mature miRNAs [10,11]. Mice with a loss of Dicer in cranial neural crest cells, the majority of the cells in craniofacial structures, display severe craniofacial deformities, including cleft palate [12-15]. In addition, mice with a deletion of miR-17-92 cluster exhibit cleft lip and palate and mandibular hypoplasia [16,17]. By contrast, overexpression of miR-17-92 in cultured mouse palatal mesenchymal cells results in increased cell proliferation [18]. Thus, precise control of miRNA expression is crucial for craniofacial development. An increasing number of studies have demonstrated that miRNA expression is altered in CL/P in humans [17,19-22]. The polymorphisms in DROSHA, miR-140, pre-miR-146a, miR4260 , and the $3^{\prime}$-UTR of the target genes are associated with nonsyndromic CL/P in humans [23-28]. Recent studies suggest that environmental factors, including maternal conditions (tobacco exposure, alcohol consumption, etc.), can alter miRNA expression during embryogenesis [29-31]. Therefore, miRNAs might be a biomarker for diagnosis and potential therapeutic targets for the condition. However, the contribution of each miRNA to $\mathrm{CL}$ remains mostly unknown.

Phenytoin, an antiseizure drug, has a teratogenic effect during pregnancy. Maternal exposure to phenytoin causes fetal hydantoin syndrome, characterized by CL/P, microcephaly, facial dysmorphism, heart defects, hypoplastic nails and fingers, and growth or mental retardation [32-34]. Phenytoin-treated animal models also show a higher incidence of $\mathrm{CL} / \mathrm{P}$, incomplete cleft lip with a Simonart's band formation, or maxillary hypoplasia [35-37]. Previous studies indicated that phenytoin exposure induces CL/P through induction of hypoxia [38-40], alterations in gene expression [41,42], suppression of RNA or protein synthesis [43], and inhibition of apoptosis at the medial edge epithelium between the MP and MNP [44]. However, it is still unknown how miRNAs induced by phenytoin contribute to CL/P. In this study, we investigated 10 candidate CL-associated miRNAs identified through our bioinformatic analysis. In addition, we evaluated whether the expression of these miRNAs was induced with phenytoin in cultured cells, and whether suppression of cell proliferation by phenytoin treatment could be rescued with normalization of miRNA expression.

\section{Results}

2.1. Overexpression of miR-181a-5p, miR-196a-5p, miR-196b-5p, and miR-710 Inhibits Cell Proliferation in Mouse Embryonic Lip Mesenchymal (MELM) and O9-1 Cells

To evaluate the role of the candidate miRNAs, primary MELM cells were treated with a miRNA mimic for either miR-98-3p, miR-101a-3p, miR-101b-3p, miR-141-3p, miR144-3p, miR-181a-5p, miR-196a-5p, miR-196b-5p, miR-200a-3p, or miR-710, which were predicted through our bioinformatic analyses [45]. Among them, miR-181a-5p, miR-196a5p, miR-196b-5p, and miR-710 mimics significantly inhibited cell proliferation in MELM cells, while miR-98-3p, miR-101a-3p, miR-101b-3p, miR-141-3p, miR-144-3p, and miR200a-3p mimics failed to inhibit cell proliferation, as shown in Figure 1A. To confirm the effect of each miRNA on cell proliferation, O9-1 cells were also used for the analysis. As Supplementary Figure S1A shows, we found that treatment with either miR-181a-5p, miR-196a-5p, miR-196b-5p, or miR-710 mimic similarly affected the cell proliferation in O9-1 cells. These results indicate that induction of miR-181a-5p, miR-196a-5p, miR-196b-5p, and miR-710 can inhibit cell proliferation in lip mesenchymal cells, leading to CL. 
A

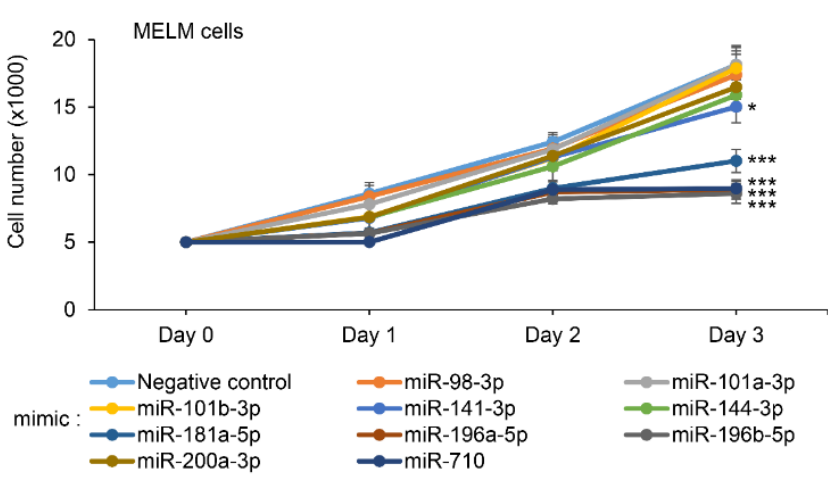

B
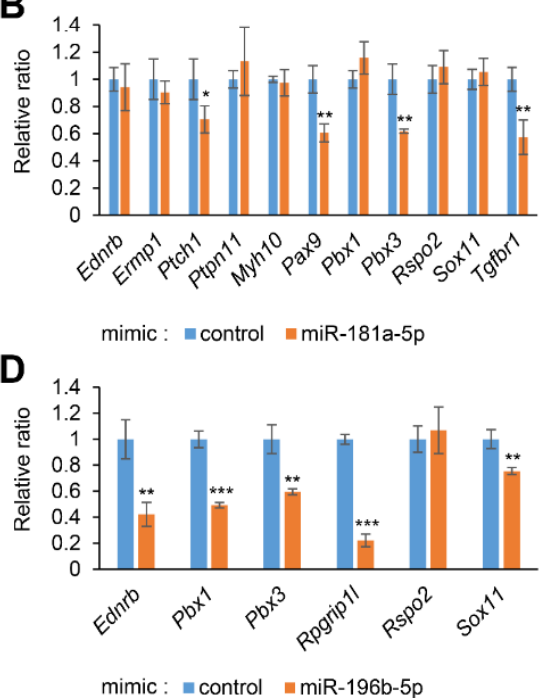

C

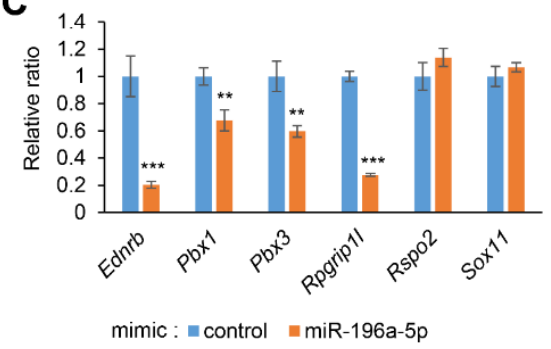

E

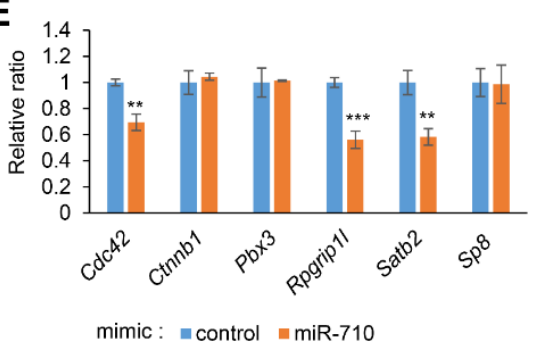

Figure 1. Effect of overexpression of the predicted microRNAs (miRNAs) on proliferation of mouse embryonic lip mesenchymal (MELM) cells. (A) Cell proliferation assays with primary MELM cells treated with the indicated miRNA mimic for control, miR-98-3p, miR-101a-3p, miR-101b-3p, miR141-3p, miR-144-3p, miR-181a-5p, miR-196a-5p, miR-196b-5p, miR-200a-3p, and miR-710. * $p<0.05$, *** $p<0.001$. Each treatment group was compared to the control. (B-E) Quantitative RT-PCR for the indicated genes after treatment of primary MELM cells with control or miR-181a-5p mimic (B), miR-196a-5p mimic (C), miR-196b-5p mimic (D), and miR-710 mimic (E). ${ }^{*} p<0.05,{ }^{* *} p<0.01$, $* * * p<0.001$ versus control $(n=6)$.

2.2. Overexpression of miR-181a-5p, miR-196a-5p, miR-196b-5p, and miR-710 Downregulates CL-Associated Genes in MELM and O9-1 Cells

To identify CL-associated genes targeted by either miR-181a-5p, miR-196a-5p, miR196b-5p, or miR-710 mimic, we performed quantitative RT-PCR analysis for the predicted target genes (11 CL-associated genes for miR-181a-5p, 6 CL-associated genes for miR196a-5p, 6 CL-associated genes for miR-196b-5p, and 6 CL-associated genes for miR-710) in MELM cells after treatment with each miRNA mimic. We found that, among them, expression of four CL-associated genes (Ptch1, Pax9, Pbx3, and Tgfbr1) in cells treated with miR-181a-5p mimic, four CL-associated genes (Ednrb, Pbx1, Pbx3, and Rpgrip1l) in cells treated with miR-196a-5p mimic, five CL-associated genes (Ednrb, Pbx1, Pbx3, Rpgrip1l, and Sox11) in cells treated with miR-196b-5p mimic, and three CL-associated genes (Cdc42, Rpgrip1l, and Satb2) in cells treated with miR-710 mimic was significantly downregulated in MELM cells; see Figure 1B-E. To compare miRNA-gene regulation between MELM and O9-1 cells, we performed quantitative RT-PCR analysis for the predicted target genes in O9-1 cells and found that gene expression was similarly altered in both MELM and O9-1 cells (Supplementary Figure S1B-E). Thus, most of the target genes of the miRNA were 
common in MELM and O9-1 cells, while there were some differences. This suggests that subtle differences in cell characteristics may alter the target genes of each miRNA.

2.3. Inhibition of miR-181a-5p, miR-196a-5p, miR-196b-5p, and miR-710 Regulates CL-Associated Genes without Affecting Cell Proliferation in MELM and O9-1 Cells

To evaluate the contribution of each miRNA to cell proliferation and gene regulation, we treated cells with a specific inhibitor for either miR-181a-5p, miR-196a-5p, miR-196b-5p, or miR-710. We found that all the inhibitors failed to alter cell proliferation in MELM cells, shown in Figure 2A, and O9-1 cells, shown in Supplementary Figure S2A. By contrast, Figure 2B-E show that the expression of several target genes was upregulated. Expression of five CL-associated genes (Ptch1, Pbx1, Pbx3, Sox11, and Tgfbr1) in cells treated with the miR-181a-5p inhibitor, five CL-associated genes (Pbx1, Pbx3, Rpgrip1l, Rspo2, and Sox11) in cells treated with the miR-196a-5p inhibitor, six CL-associated genes (Ednrb, Pbx1, Pbx3, Rpgrip1l, Rspo2, and Sox11) in cells treated with the miR-196b-5p inhibitor, and four CL-associated genes (Cdc42, Ctnnb1, Pbx3, and Rpgrip1l) in cells treated with miR-710 inhibitor was altered in a dose-dependent manner in MELM cells. Similarly, we found that treatment with each inhibitor induced expression of the target genes in O9-1 cells, as seen in Supplementary Figures S2B-E and S3. Taken together, miR-181a-5p, miR-196a-5p, miR-196b-5p, and miR-710 can regulate the expression of multiple CL-associated genes in a dose-dependent manner in MELM and O9-1 cells (miR-181a-5p regulates the expression of Ptch1 and Tgfbr1; miR-196a-5p of Pbx1, Pbx3, and Rpgrip1l; miR-196b-5p of Ednrb, Pbx1, Pbx3, and Rpgrip1l; and miR-710 of Cdc42 and Rpgrip1l). We confirmed that these genes contain binding sites for the predicted miRNA with an in silico analysis, shown in Supplementary Figures S4-S7.

A

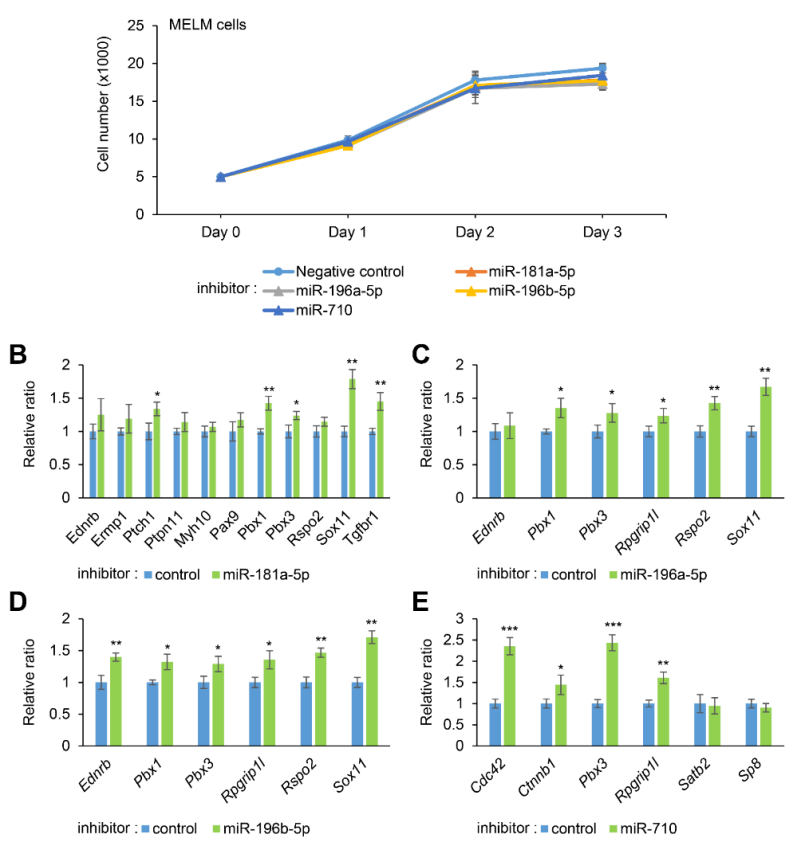

Figure 2. Effect of inhibition of miR-181a-5p, miR-196a-5p, miR-196b-5p, or miR-710 on proliferation of mouse embryonic lip mesenchymal (MELM) cells. (A) Cell proliferation assays in primary MELM cells treated with control, miR-181a-5p, miR-196a-5p, miR-196b-5p, or miR-710 inhibitor. (B-E) Quantitative RT-PCR for the indicated genes after treatment of primary MELM cells with control or miR-181a-5p inhibitor (B), miR-196a- inhibitor (C), miR-196b-5p inhibitor (D), and miR-710 inhibitor (E). ${ }^{*} p<0.05,{ }^{* *} p<0.01,{ }^{* * *} p<0.001$ versus control $(n=6)$. 


\subsection{Phenytoin Inhibits Cell Proliferation through miR-196a-5p Induction in MELM and O9-1 Cells}

To test whether the expression of candidate miRNAs could be altered with phenytoin, we performed cell proliferation assays in MELM and O9-1 cells treated with 25 or $50 \mu \mathrm{g} / \mathrm{mL}$ phenytoin. We found that cell proliferation was significantly inhibited with phenytoin, in a dose-dependent manner, in these cells, as shown in Figure 3A,B. Interestingly, miR-196a-5p expression was specifically upregulated with phenytoin treatment in both MELM and O9-1 cells, while expression of miR-181a-5p, miR-196b-5p, and miR-710 was not changed or detected under phenytoin treatment, as Figure 3C,D show.

A
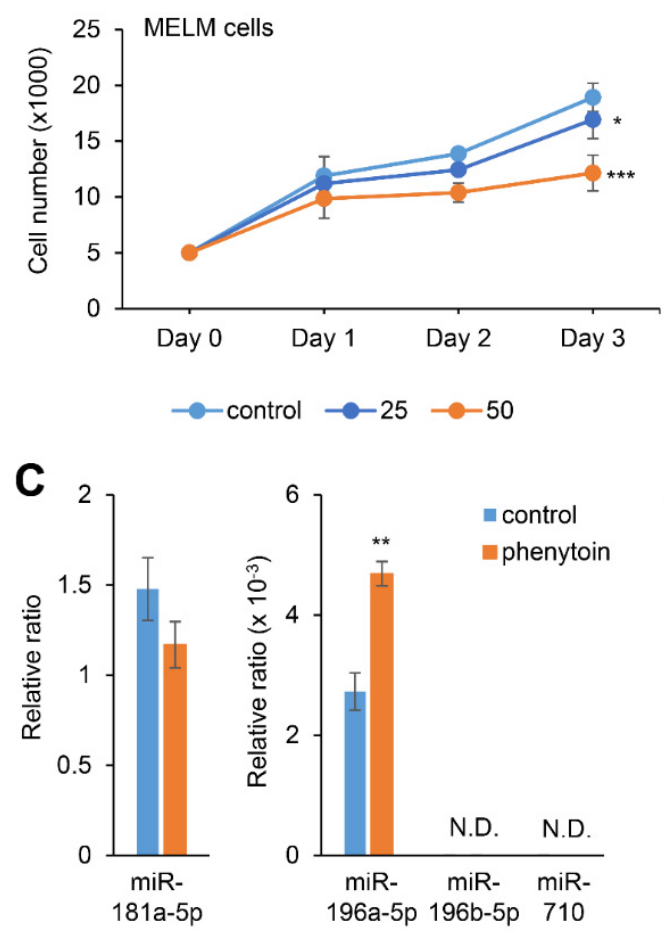

B

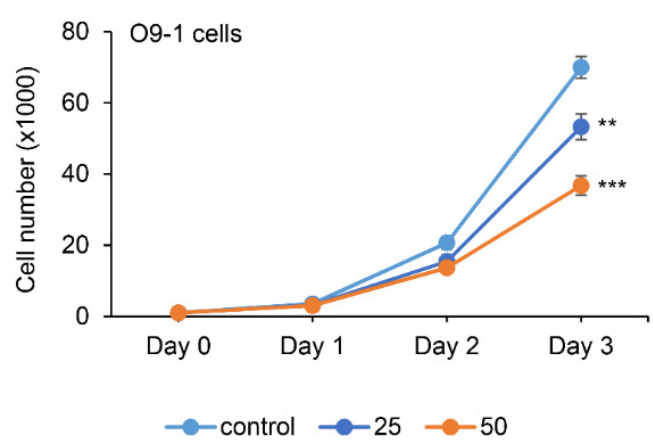

D

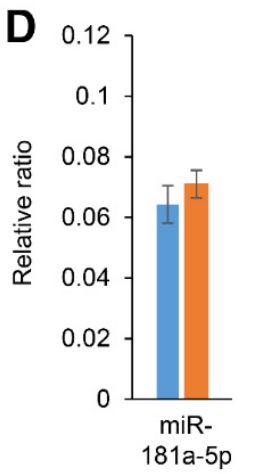

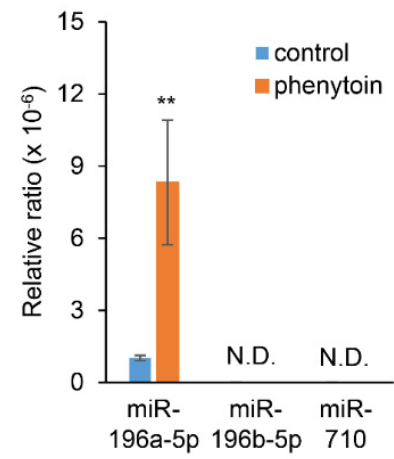

Figure 3. Influence of phenytoin on cell proliferation and microRNA (miRNA) expression in mouse embryonic lip mesenchymal (MELM) and O9-1 cells. (A,B) Cell proliferation assays with MELM cells (A) and O9-1 cells (B) treated with 25 or $50 \mu \mathrm{g} / \mathrm{mL}$ phenytoin for 24,48 , and $72 \mathrm{~h} .{ }^{*} p<0.05$, *** $p<0.001$ versus control $(n=6)$. (C,D) Quantitative RT-PCR for miR-181a-5p, miR-196a-5p, miR196b-5p, or miR-710 after treatment of MELM cells (C) and O9-1 cells (D) with phenytoin for $72 \mathrm{~h}$. ** $p<0.01(n=6)$. N.D., not detected.

\subsection{Inhibition of miR-196a-5p Partially Rescues Cell Proliferation in Cells Treated with Phenytoin}

To evaluate the functional relevance of miR-196a-5p in phenytoin-induced cell proliferation defects, we treated MELM and O9-1 cells with miR-196a-5p inhibitor under phenytoin treatment conditions. Figure 4A,B show that the miR-196a-5p inhibitor partially restored cell proliferation in both MELM and O9-1 cells. In addition, we found that the expression of Ednrb, Pbx1, Pbx3, Rpgrip1l, and Rspo2 was almost fully normalized with miR-196a-5p inhibitor, under phenytoin conditions, in MELM and O9-1 cells, as seen in Figure 4C,D. Taken together, our results indicate that phenytoin inhibits the proliferation of MELM and O9-1 cells through miR-196a-5p expression. 
A

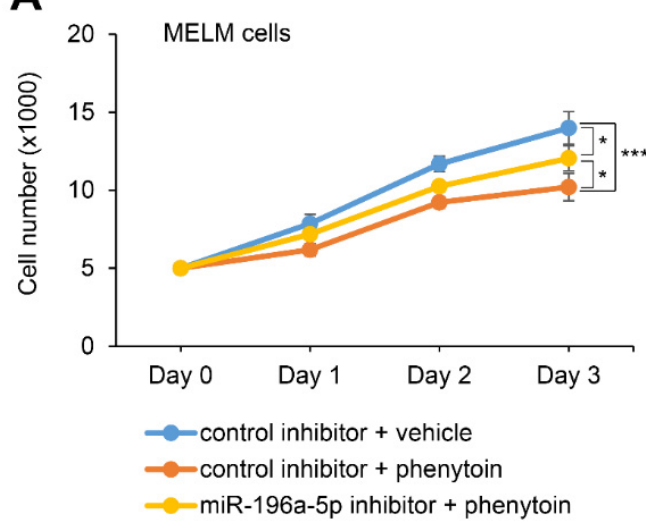

C

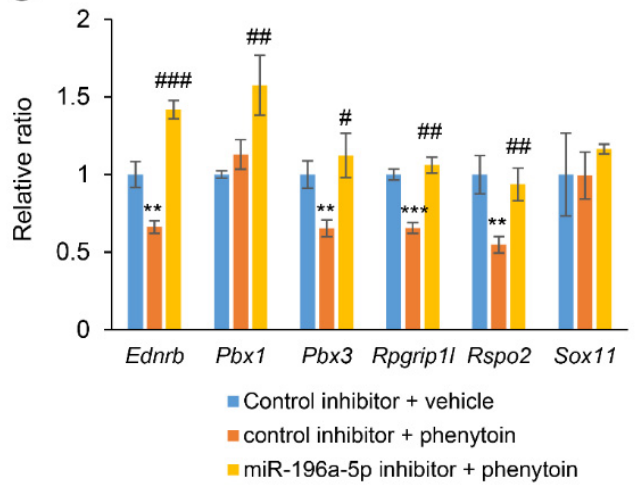

B

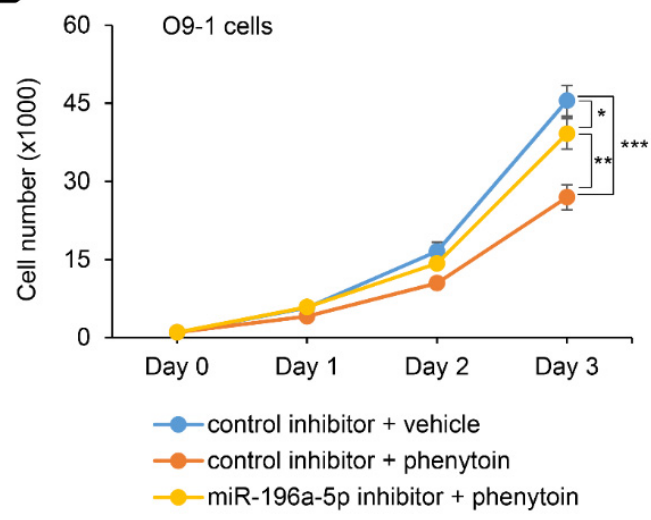

D

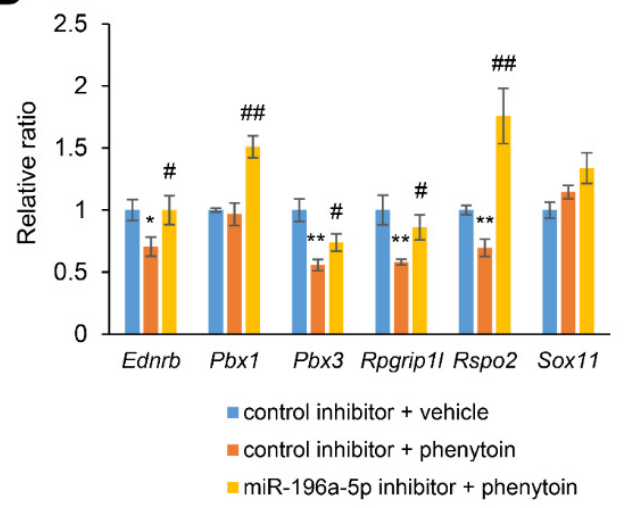

Figure 4. Normalization of miR-196a-5p expression restores phenytoin-induced cell proliferation defects in mouse embryonic lip mesenchymal (MELM) and O9-1 cells. (A,B) Cell proliferation assays with MELM cells (A) or O9-1 cells (B) treated with $50 \mu \mathrm{g} / \mathrm{mL}$ phenytoin under miR-196a-5p inhibitor for 24,48 , or $72 \mathrm{~h}$. ${ }^{*} p<0.05,{ }^{* *} p<0.01$, and ${ }^{* * *} p<0.001$. $n=6$ per group. (C,D) Quantitative RT-PCR for the indicated genes after treatment of MELM cells (C) or O9-1 cells (D) with phenytoin under miR-196a-5p inhibitor for $72 \mathrm{~h}$. ${ }^{*} p<0.05,{ }^{* *} p<0.01$, and ${ }^{* * *} p<0.001$ versus control inhibitor + vehicle. ${ }^{\#} p<0.05,{ }^{\# \#} p<0.01$, and ${ }^{\# \#} p<0.001$ versus control inhibitor + phenytoin. $n=6$ per group.

\section{Discussion}

The contribution and distribution of miRNAs and their networks are still mostly unknown in lip formation. To predict functional miRNAs in lip development, we conducted a bioinformatic analysis for CL-associated genes identified through a systematic literature review and a mouse genome informatics (MGI) database search [45]. In the present study, we experimentally evaluated the predicted candidate miRNAs, and found that miR-181a5p, miR-196a-5p, miR-196b-5p, and miR-710 could suppress the proliferation of MELM cells.

A growing number of miRNA profiling studies shows a significant association of miRNA to nonsyndromic CL/P $[20,46]$. However, the relationship between CL etiology and miRNA remains unclear. This study found that overexpression of miR-181a-5p, miR-196a5p, miR-196b-5p, and miR-710 inhibited cell proliferation through suppression of genes associated with mouse CL. The miR-181a-5p, which belongs to the miR-181s family, including miR-181a, $-b,-c$, and $-d$, is active in cell proliferation and differentiation in development and cancers. For instance, miR-181 plays a crucial role in the terminal differentiation of skeletal myoblasts by suppressing HOXA11, a transcription factor that induces MyoD [47], and in the differentiation of B-lymphocytes through suppression of Notch signaling [48]. In addition, miR-181a-5p suppresses proliferation and induces apoptosis of glomerular mesangial cells by suppressing KLF6 and BCL2 expression via reduction of WNT/ $\beta$-catenin signaling in human diabetic nephropathy [49] and of glioma cell lines through suppression 
of the gene encoding for Cyclin B1 [50]. miR-196a-5p and miR-196b-5p, which belong to the miR-196 family of genes and are located on chromosomes 11 and 6, respectively, affect cell proliferation [51]. For instance, miR-196 inhibits the expression of Hoxb8, resulting in downregulation of Shh expression in mouse forelimb development [52], whereas its overexpression suppresses cell proliferation and migration by suppressing HOXA9 in human osteosarcoma cell lines [53]. In addition, miR-196a regulates the proliferation of bone marrow mesenchymal stem cells by suppressing HOXB7 [54]. Although miR-181, miR-196, and miR-710 have not yet been associated with craniofacial developmental defects, our results suggest that dysregulation of these miRNAs may contribute to the pathogenesis of CL. The contributions of these miRNAs will be further evaluated in mice developing CL or in mice overexpressing an individual miRNA.

In the present study, we showed miRNA-mediated gene regulation in MELM and O9-1 cells. We found that miR-181a-5p regulated the expression of Ptch1 and Tgfbr1; miR196a-5p of Pbx1,Pbx3, and Rpgrip1l; miR-196b-5p of Ednrb, Pbx1, Pbx3, and Rpgrip1l; and miR-710 of Cdc42 and Rpgrip1l in a dose-dependent manner. The pre-B-cell leukemia transcription factor (PBX), a member of the TALE/PBX homeobox family, acts as a cofactor of HOX to modulate the DNA binding and transcriptional activity of the HOX transcription factor. The complex composed of PBX::HOX plays essential roles in embryonic development $[55,56]$. For example, the anterior-posterior segmentation of rhombomeres and pharyngeal arches (PAs) is regulated through the expression pattern of Hox genes (namely Hox code) [57-59]. PBX proteins activate this Hox code. Thus, migration of neural crest cells into the PAs, and consequent craniofacial morphogenesis, depends on the HOX::PBX complex. Therefore, miR-196 may regulate cell proliferation and morphogenesis through downregulation of the HOX::PBX complex. The cell division control protein 42 (CDC42), a Rho small GTPase, plays roles in cell migration, cell cycle regulation, and differentiation [60]. Rpgrip1-like (RPGRIP1L) is located at the transition zone of the primary cilia, acting as a ciliary gatekeeper, and regulates ciliary protein composition [61,62]. Absence of Rpgrip 11 causes ciliogenesis defects and a failure in the proteolytic process of converting full-length GLI3 to a cleaved repressor form (GLI3R) that disrupts HH signaling [63]. Patched1 (PTCH1), a HH receptor, is located on the primary cilium in the absence of $\mathrm{HH}$ ligands; when $\mathrm{HH}$ ligands bind to PTCH1, the HH ligand::PTCH1 complex exits from the primary cilium, promoting Smoothened (SMO) to the primary cilium, which results in induction of $\mathrm{HH}$ signaling. Thus, these seven genes are all associated with critical signaling pathways related to lip formation, and, therefore, upregulation of miRNAs might induce CL through the dysregulation of these pathways.

We investigated whether and how phenytoin altered miRNA expression that decreased cell proliferation through the expression of genes associated with CL using MELM and O9-1 cells. We found that phenytoin specifically induced miR-196a-5p, which suppressed the expression of genes associated with CL. While expression of some predicted genes, such as $P b x 1$ and Sox 11 targeted by miR-196a-5p, was not changed by phenytoin in MELM and O9-1 cells, these genes may be regulated by a combination of other miRNAs or through feedback loops reported in mice and cell lines [64-67].

A previous study showed that phenytoin treatment suppressed cell proliferation and induced apoptosis in cultured mouse embryonic palatal mesenchymal cells [68]. In addition, treatment of human palatal mesenchymal cells with diphenylhydantoin alters the expression of genes related to the cytoskeleton and cell adhesion [69]. Interestingly, diphenylhydantoin reduces biosynthesis of glycosaminoglycan and collagens in healthy human palatal fibroblasts but not in palatal fibroblasts from individuals with cleft palate [70]. The expression of the special AT-rich sequence-binding protein 2 (Satb2), a DNA binding protein associated with transcriptional regulation and craniofacial patterning, is suppressed in embryos exposed to phenytoin [42], and our study shows that there is no dose-dependent regulation of Satb2 expression by miR-710.

In conclusion, overexpression of miR-181a-5p, miR-196a-5p, miR-196b-5p, and miR710 inhibits cell proliferation in MELM and O9-1 cells through CL-related genes. Moreover, 
the phenytoin-induced cell proliferation defect is associated with miR-196a-5p upregulation. Since more than half of the cases of $\mathrm{CL} / \mathrm{P}$ are nonsyndromic and both environmental and genetic factors are involved in $\mathrm{CL} / \mathrm{P}$, the identification of miRNAs influenced by the maternal environment would be clinically relevant to develop a way to prevent and diagnose $\mathrm{CL} / \mathrm{P}$. In addition, understanding the miRNA-gene regulation process will shed light on the mechanism of dynamic change in gene expression during embryogenesis.

\section{Methods}

\subsection{Animals}

C57BL/6J mice were obtained from The Jackson Laboratory. All mice were maintained in the animal facility of UTHealth. The protocol was reviewed and approved by the Animal Welfare Committee (AWC) and the Institutional Animal Care and Use Committee (IACUC) of UTHealth.

\subsection{Cell Culture}

Primary MELM cells were isolated from the anterior half of the maxillary process, a developing lip region, at E11.5, as previously described [45]. The maxillary processes were dissected in sterile Dulbecco's phosphate-buffered saline (DPBS) without $\mathrm{Ca}^{2+}$ and $\mathrm{Mg}^{2+}$ and were pooled. To isolate single-cell suspensions, the tissues were incubated with $0.25 \%$ trypsin $/ 0.05 \%$ ethylenediaminetetraacetic acid (EDTA) for $10 \mathrm{~min}$ at $37^{\circ} \mathrm{C}$. MELM cells were cultured in Dulbecco's Modified Eagle Medium (DMEM) supplemented with $10 \%$ fetal bovine serum (FBS), antibiotics (penicillin and streptomycin), L-glutamine, $\beta$-mercaptoethanol, and nonessential amino acids. MELM cells were passaged up to two times. Mouse cranial neural crest O9-1 cells (SCC049, Sigma-Aldrich, St. Louis, MO, USA) were cultured under a conditioned medium provided by a mouse embryonic fibroblast cell line called STO cells (CRL-1503, ATCC), as previously described [45].

\subsection{Cell Proliferation Assay}

Cells were plated onto 96-well cell culture plates at a density of 5000 cells (MELM cells) or 1000 cells (O9-1 cells) per well and treated with a mimic for negative control, miR-98-3p, miR-101a-3p, miR-101b-3p, miR-141-3p, miR-144-3p, miR-181a-5p, miR-196a5p, miR-196b-5p, miR-200a-3p, and miR-710 (mirVana miRNA mimic, Thermo Fisher Scientific, Waltham, MA, USA), or an inhibitor for negative control, miR-181a-5p, miR196a-5p, miR-196b-5p, and miR-710 (mirVana miRNA inhibitor, Thermo Fisher Scientific), using Lipofectamine RNAiMAX transfection reagent (Thermo Fisher Scientific), according to manufacturer protocol ( 3 pmol of mimic and $0.3 \mu \mathrm{L}$ of transfection reagent in $100 \mu \mathrm{L}$ DMEM per well). Cell proliferation was measured using the Cell Counting Kit 8 (Dojindo Molecular Technologies, Gaithersburg, MD, USA) at 24, 48, or $72 \mathrm{~h}$ after each treatment ( $n=6$ per group).

\subsection{Quantitative RT-PCR}

MELM and O9-1 cells were plated onto a 35-mm dish at a density of 20,000 cells per dish. When the cells reached $80 \%$ confluence, the cells were treated with a mimic or inhibitor for the negative control, miR-181a-5p, miR-196a-5p, miR-196b-5p, or miR-710 at 3 pmol in $6 \mu \mathrm{L}$ of transfection reagent (Lipofectamine RNAiMAX transfection reagent in $2 \mathrm{~mL}$ DMEM per dish). One day after treatment, total RNA was extracted with the QIAshredder and miRNeasy Mini Kit (QIAGEN, Hilden, Germany), according to manufacturer instructions. Total RNA $(1 \mu \mathrm{g})$ from each sample was reverse-transcribed using iScript Reverse Transcription Supermix for qRT-PCR (Bio-Rad, Hercules, CA, USA), and cDNA was amplified with the iTaq Universal SYBR Green Supermix (Bio-Rad) on a CFX96 Touch Real-Time PCR Detection System (Bio-Rad). The amount of each mRNA was normalized by Gapdh. The PCR primers used in this study are listed in Supplemental Table S1. 
4.5. In Silico Analysis for Binding Sites of miR-181a-5p, miR-196a-5p, miR-196b-5p, and miR-710 on the CL-Associated Genes

The mature sequence of miR-181a-5p (5'-AACAUUCAACGCUGUCGGUGAGU-3'), miR-196a-5p (5'-UAGGUAGUUUCAUGUUGUUGGG-3'), miR-196b-5p (5'-UAGGUAGUUUCCUGUUGUUGGG$\left.3^{\prime}\right)$, and miR-710 (5'-UGUGGGGCUGUGGCCAUCAAGAA-3') and the 3'-UTR of CL-associated genes (Cdc42, Ednrb, Pbx1, Pbx3, Ptch1, Rpgrip1l, and Tgfbr1) were analyzed by Clustal Omega to predict a binding site for each miRNA.

\subsection{Phenytoin Exposure to Cultured Cells}

For cell proliferation assays, the cells were plated onto 96-well cell culture plates at a density of 5000 per well (MELM cells) or 1000 per well (O9-1 cells) and treated with phenytoin (D4505, Sigma-Aldrich) at 25 or $50 \mu \mathrm{g} / \mathrm{mL}$ for 24,48 , or $72 \mathrm{~h}$. For quantitative RT-PCR, the cells were plated onto a 35-mm dish at a density of 25,000 (MELM cells) or 15,000/well (O9-1 cells) and treated with phenytoin (D4505, Sigma-Aldrich) at $50 \mu \mathrm{g} / \mathrm{mL}$ for $72 \mathrm{~h}$.

\subsection{Rescue Experiment Against Phenytoin Toxicant}

MELM and O9-1 cells were plated onto 60-mm dishes at a density of 400,000 per well and 200,000 per well, respectively. After $24 \mathrm{~h}$, the cells were transfected with either miR196a-5p inhibitor (3 pmol) or control miRNA inhibitor ( 3 pmol; mirVana, Thermo Fisher Scientific) using Lipofectamine RNAiMAX transfection reagent (Thermo Fisher Scientific), according to manufacturer protocol $(12 \mu \mathrm{L}$ of transfection reagent in $4 \mathrm{~mL}$ DMEM per dish). The cells were harvested $24 \mathrm{~h}$ after transfection and used for further experiments (cell proliferation assays and quantitative RT-PCR).

\subsection{Statistical Analysis}

A $p$-value less than 0.05 in two-tailed Student's $t$-tests or post hoc Tukey-Kramer's test was considered to be statistically significant. For all graphs, data were parametric and represented as mean \pm standard deviation (SD).

Supplementary Materials: The following are available online at https:/ /www.mdpi.com/1422-006 $7 / 22 / 4 / 1746 /$ s1.

Author Contributions: Conceived and designed the experiments: H.Y., A.S., and J.I. Performed the experiments: H.Y. and S.S.R. Prepared the manuscript: H.Y., A.S., and J.I. All authors have read and agreed to the published version of the manuscript.

Funding: This work was partially supported by grants from the National Institute of Dental and Craniofacial Research (https:/ / www.nidcr.nih.gov (accessed on 9 February 2021)) (R01DE026767, R01DE029818, R03DE026509, and R03DE028340 to J.I.). The funders had no role in study design, data collection and analysis, decision to publish, or preparation of the manuscript.

Institutional Review Board Statement: The protocol was reviewed and approved by the Animal Welfare Committee (AWC) and the Institutional Animal Care and Use Committee (IACUC) of UTHealth.

Informed Consent Statement: Not applicable.

Data Availability Statement: All relevant data are within the manuscript and its Supporting Information files. The datasets generated and analyzed during the current study are also available from the corresponding author upon request.

Conflicts of Interest: The authors declare no conflict of interest. 


\section{References}

1. Beaty, T.H.; Marazita, M.L.; Leslie, E.J. Genetic factors influencing risk to orofacial clefts: Today's challenges and tomorrow's opportunities. F1000Research 2016, 5, 2800. [CrossRef]

2. Gonseth, S.; Shaw, G.M.; Roy, R.; Segal, M.R.; Asrani, K.; Rine, J.; Wiemels, J.; Marini, N.J. Epigenomic profiling of newborns with isolated orofacial clefts reveals widespread DNA methylation changes and implicates metastable epiallele regions in disease risk. Epigenetics 2019, 14, 198-213. [CrossRef]

3. Grosen, D.; Bille, C.; Petersen, I.; Skytthe, A.; Hjelmborg, J.; Pedersen, J.K.; Murray, J.C.; Christensen, K. Risk of oral clefts in twins. Epidemiology 2011, 22, 313-319. [CrossRef]

4. Krauss, R.S.; Hong, M. Gene-Environment Interactions and the Etiology of Birth Defects. Curr. Top. Dev. Biol. 2016, 116, 569-580. [CrossRef]

5. Jiang, R.; Bush, J.O.; Lidral, A.C. Development of the upper lip: Morphogenetic and molecular mechanisms. Dev. Dyn. 2006, 235, 1152-1166. [CrossRef] [PubMed]

6. Suzuki, A.; Sangani, D.R.; Ansari, A.; Iwata, J. Molecular mechanisms of midfacial developmental defects. Dev. Dyn. 2016, 245, 276-293. [CrossRef]

7. Matsuyama, H.; Suzuki, H.I. Systems and Synthetic microRNA Biology: From Biogenesis to Disease Pathogenesis. Int. J. Mol. Sci. 2019, 21, 132. [CrossRef]

8. Stavast, C.J.; Erkeland, S.J. The Non-Canonical Aspects of MicroRNAs: Many Roads to Gene Regulation. Cells 2019, 8, 1465. [CrossRef] [PubMed]

9. Ha, M.; Kim, V.N. Regulation of microRNA biogenesis. Nat. Rev. Mol. Cell Biol. 2014, 15, 509-524. [CrossRef]

10. Treiber, T.; Treiber, N.; Meister, G. Regulation of microRNA biogenesis and its crosstalk with other cellular pathways. Nat. Rev. Mol. Cell Biol. 2019, 20, 5-20. [CrossRef]

11. Lee, Y.; Ahn, C.; Han, J.; Choi, H.; Kim, J.; Yim, J.; Lee, J.; Provost, P.; Radmark, O.; Kim, S.; et al. The nuclear RNase III Drosha initiates microRNA processing. Nature 2003, 425, 415-419. [CrossRef]

12. Zehir, A.; Hua, L.L.; Maska, E.L.; Morikawa, Y.; Cserjesi, P. Dicer is required for survival of differentiating neural crest cells. Dev. Biol. 2010, 340, 459-467. [CrossRef] [PubMed]

13. Nie, X.; Wang, Q.; Jiao, K. Dicer activity in neural crest cells is essential for craniofacial organogenesis and pharyngeal arch artery morphogenesis. Mech. Dev. 2011, 128, 200-207. [CrossRef] [PubMed]

14. Huang, T.; Liu, Y.; Huang, M.; Zhao, X.; Cheng, L. Wnt1-cre-mediated conditional loss of Dicer results in malformation of the midbrain and cerebellum and failure of neural crest and dopaminergic differentiation in mice. J. Mol. Cell Biol. 2010, 2, 152-163. [CrossRef]

15. Barritt, L.C.; Miller, J.M.; Scheetz, L.R.; Gardner, K.; Pierce, M.L.; Soukup, G.A.; Rocha-Sanchez, S.M. Conditional deletion of the human ortholog gene Dicer1 in Pax2-Cre expression domain impairs orofacial development. Indian J. Hum. Genet. 2012, 18, 310-319. [CrossRef] [PubMed]

16. Ries, R.J.; Yu, W.; Holton, N.; Cao, H.; Amendt, B.A. Inhibition of the miR-17-92 Cluster Separates Stages of Palatogenesis. J. Dent. Res. 2017, 96, 1257-1264. [CrossRef] [PubMed]

17. Wang, J.; Bai, Y.; Li, H.; Greene, S.B.; Klysik, E.; Yu, W.; Schwartz, R.J.; Williams, T.J.; Martin, J.F. MicroRNA-17-92, a direct Ap-2alpha transcriptional target, modulates T-box factor activity in orofacial clefting. PLoS Genet. 2013, 9, e1003785. [CrossRef]

18. Li, L.; Shi, J.Y.; Zhu, G.Q.; Shi, B. MiR-17-92 cluster regulates cell proliferation and collagen synthesis by targeting TGFB pathway in mouse palatal mesenchymal cells. J. Cell. Biochem. 2012, 113, 1235-1244. [CrossRef]

19. Mukhopadhyay, P.; Smolenkova, I.; Warner, D.; Pisano, M.M.; Greene, R.M. Spatio-Temporal Expression and Functional Analysis of miR-206 in Developing Orofacial Tissue. MicroRNA 2019, 8, 43-60. [CrossRef]

20. Wang, S.; Sun, C.; Meng, Y.; Zhang, B.; Wang, X.; Su, Y.; Shi, L.; Zhao, E. A pilot study: Screening target miRNAs in tissue of nonsyndromic cleft lip with or without cleft palate. Exp. Ther. Med. 2017, 13, 2570-2576. [CrossRef] [PubMed]

21. Wu, N.; Yan, J.; Han, T.; Zou, J.; Shen, W. Integrated assessment of differentially expressed plasma microRNAs in subtypes of nonsyndromic orofacial clefts. Medicine 2018, 97, e11224. [CrossRef]

22. Grassia, V.; Lombardi, A.; Kawasaki, H.; Ferri, C.; Perillo, L.; Mosca, L.; Delle Cave, D.; Nucci, L.; Porcelli, M.; Caraglia, M. Salivary microRNAs as new molecular markers in cleft lip and palate: A new frontier in molecular medicine. Oncotarget 2018, 9, 18929-18938. [CrossRef]

23. Xu, M.; Ma, L.; Lou, S.; Du, Y.; Yin, X.; Zhang, C.; Fan, L.; Wang, H.; Wang, Z.; Zhang, W.; et al. Genetic variants of microRNA processing genes and risk of non-syndromic orofacial clefts. Oral Dis. 2018, 24, 422-428. [CrossRef]

24. Li, L.; Meng, T.; Jia, Z.; Zhu, G.; Shi, B. Single nucleotide polymorphism associated with nonsyndromic cleft palate influences the processing of miR-140. Am. J. Med.Genet. Part A 2010, 152, 856-862. [CrossRef]

25. Pan, Y.; Li, D.; Lou, S.; Zhang, C.; Du, Y.; Jiang, H.; Zhang, W.; Ma, L.; Wang, L. A functional polymorphism in the pre-miR-146a gene is associated with the risk of nonsyndromic orofacial cleft. Hum. Mutat. 2018, 39, 742-750. [CrossRef]

26. Zhu, G.; Zhang, C.; Wang, Y.; Wang, Y.; Li, D.; Yu, X.; Zhu, W.; Fu, C.; Lou, S.; Fan, L.; et al. Variants in miRNA regulome and their association with the risk of nonsyndromic orofacial clefts. Epigenomics 2020, 12, 1109-1121. [CrossRef]

27. Li, D.; Zhang, H.; Ma, L.; Han, Y.; Xu, M.; Wang, Z.; Jiang, H.; Zhang, W.; Wang, L.; Pan, Y. Associations between microRNA binding site SNPs in FGFs and FGFRs and the risk of non-syndromic orofacial cleft. Sci. Rep. 2016, 6, 31054. [CrossRef] 
28. Rattanasopha, S.; Tongkobpetch, S.; Srichomthong, C.; Siriwan, P.; Suphapeetiporn, K.; Shotelersuk, V. PDGFRa mutations in humans with isolated cleft palate. EJHG 2012, 20, 1058-1062. [CrossRef]

29. Li, L.; Zhu, G.Q.; Meng, T.; Shi, J.Y.; Wu, J.; Xu, X.; Shi, B. Biological and epidemiological evidence of interaction of infant genotypes at Rs7205289 and maternal passive smoking in cleft palate. Am. J. Med. Genet. Part A 2011, 155, 2940-2948. [CrossRef] [PubMed]

30. Mahnke, A.H.; Sideridis, G.D.; Salem, N.A.; Tseng, A.M.; Carter, R.C.; Dodge, N.C.; Rathod, A.B.; Molteno, C.D.; Meintjes, E.M.; Jacobson, S.W.; et al. Infant circulating MicroRNAs as biomarkers of effect in fetal alcohol spectrum disorders. Sci. Rep. 2021, 11, 1429. [CrossRef] [PubMed]

31. Balaraman, S.; Schafer, J.J.; Tseng, A.M.; Wertelecki, W.; Yevtushok, L.; Zymak-Zakutnya, N.; Chambers, C.D.; Miranda, R.C. Plasma miRNA Profiles in Pregnant Women Predict Infant Outcomes following Prenatal Alcohol Exposure. PLoS ONE 2016, 11, e0165081. [CrossRef]

32. Jones, K.L.; Lacro, R.V.; Johnson, K.A.; Adams, J. Pattern of malformations in the children of women treated with carbamazepine during pregnancy. N. Engl. J. Med. 1989, 320, 1661-1666. [CrossRef]

33. Hegde, A.; Kaur, A.; Sood, A.; Dhanorkar, M.; Varma, H.T.; Singh, G.; Saini, A.G.; Kumar, P. Fetal Hydantoin Syndrome. J. Pediatr. 2017, 188, 304. [CrossRef]

34. Webster, W.S.; Howe, A.M.; Abela, D.; Oakes, D.J. The relationship between cleft lip, maxillary hypoplasia, hypoxia and phenytoin. Curr. Pharm. Des. 2006, 12, 1431-1448. [CrossRef]

35. Sullivan-Jones, P.; Hansen, D.K.; Sheehan, D.M.; Holson, R.R. The effect of teratogens on maternal corticosterone levels and cleft incidence in A/J mice. J. Craniofac. Genet. Dev. Biol. 1992, 12, 183-189.

36. Karolyi, J.; Erickson, R.P.; Liu, S.; Killewald, L. Major effects on teratogen-induced facial clefting in mice determined by a single genetic region. Genetics 1990, 126, 201-205. [CrossRef] [PubMed]

37. Sulik, K.K.; Johnston, M.C.; Ambrose, L.J.; Dorgan, D. Phenytoin (dilantin)-induced cleft lip and palate in A/J mice: A scanning and transmission electron microscopic study. Anat. Rec. 1979, 195, 243-255. [CrossRef] [PubMed]

38. Ritchie, H.E.; Oakes, D.; Farrell, E.; Ababneh, D.; Howe, A. Fetal hypoxia and hyperglycemia in the formation of phenytoininduced cleft lip and maxillary hypoplasia. Epilepsia Open 2019, 4, 443-451. [CrossRef] [PubMed]

39. Millicovsky, G.; Johnston, M.C. Maternal hyperoxia greatly reduces the incidence of phenytoin-induced cleft lip and palate in A/J mice. Science 1981, 212, 671-672. [CrossRef]

40. Nakatomi, M.; Ludwig, K.U.; Knapp, M.; Kist, R.; Lisgo, S.; Ohshima, H.; Mangold, E.; Peters, H. Msx1 deficiency interacts with hypoxia and induces a morphogenetic regulation during mouse lip development. Development 2020, 147. [CrossRef]

41. Gelineau-van Waes, J.; Bennett, G.D.; Finnell, R.H. Phenytoin-induced alterations in craniofacial gene expression. Teratology 1999, 59, 23-34. [CrossRef]

42. Mao, X.Y.; Tang, S.J. Effects of phenytoin on Satb2 and Hoxa2 gene expressions in mouse embryonic craniofacial tissue. Biochem. Cell Biol. 2010, 88, 731-735. [CrossRef] [PubMed]

43. Sonawane, B.R.; Goldman, A.S. Susceptibility of mice to phenytoin-induced cleft palate correlated with inhibition of fetal palatal RNA and protein synthesis (41255). Proc. Soc. Exp. Biol. Med. 1981, 168, 175-179. [CrossRef]

44. Goldman, A.S.; Baker, M.K.; Piddington, R.; Herold, R. Inhibition of programmed cell death in mouse embryonic palate in vitro by cortisol and phenytoin: Receptor involvement and requirement of protein synthesis. Proc. Soc. Exp. Biol. Med. 1983, 174, 239-243. [CrossRef]

45. Suzuki, A.; Yoshioka, H.; Summakia, D.; Desai, N.G.; Jun, G.; Jia, P.; Loose, D.S.; Ogata, K.; Gajera, M.V.; Zhao, Z.; et al. MicroRNA-124-3p suppresses mouse lip mesenchymal cell proliferation through the regulation of genes associated with cleft lip in the mouse. BMC Genom. 2019, 20, 852. [CrossRef]

46. Li, J.; Zou, J.; Li, Q.; Chen, L.; Gao, Y.; Yan, H.; Zhou, B.; Li, J. Assessment of differentially expressed plasma microRNAs in nonsyndromic cleft palate and nonsyndromic cleft lip with cleft palate. Oncotarget 2016, 7, 86266-86279. [CrossRef]

47. Naguibneva, I.; Ameyar-Zazoua, M.; Polesskaya, A.; Ait-Si-Ali, S.; Groisman, R.; Souidi, M.; Cuvellier, S.; Harel-Bellan, A. The microRNA miR-181 targets the homeobox protein Hox-A11 during mammalian myoblast differentiation. Nat. Cell Biol. 2006, 8, 278-284. [CrossRef]

48. Chen, C.Z.; Li, L.; Lodish, H.F.; Bartel, D.P. MicroRNAs modulate hematopoietic lineage differentiation. Science 2004, 303, 83-86. [CrossRef]

49. Liang, X.; Xu, W. miR-181a-5p regulates the proliferation and apoptosis of glomerular mesangial cells by targeting KLF6. Exp. Ther. Med. 2020, 20, 1121-1128. [CrossRef]

50. Wang, F.; Sun, J.Y.; Zhu, Y.H.; Liu, N.T.; Wu, Y.F.; Yu, F. MicroRNA-181 inhibits glioma cell proliferation by targeting cyclin B1. Mol. Med. Rep. 2014, 10, 2160-2164. [CrossRef]

51. Chen, C.; Zhang, Y.; Zhang, L.; Weakley, S.M.; Yao, Q. MicroRNA-196: Critical roles and clinical applications in development and cancer. J. Cell. Mol. Med. 2011, 15, 14-23. [CrossRef] [PubMed]

52. Hornstein, E.; Mansfield, J.H.; Yekta, S.; Hu, J.K.; Harfe, B.D.; McManus, M.T.; Baskerville, S.; Bartel, D.P.; Tabin, C.J. The microRNA miR-196 acts upstream of Hoxb8 and Shh in limb development. Nature 2005, 438, 671-674. [CrossRef]

53. Cao, Y.; Wu, B.; Wang, D.; Bi, Z. miR-196 acts as a tumor suppressor in osteosarcoma by targeting HOXA9. Int. J. Clin. Exp. Pathol. 2018, 11, 4579-4584. 
54. Candini, O.; Spano, C.; Murgia, A.; Grisendi, G.; Veronesi, E.; Piccinno, M.S.; Ferracin, M.; Negrini, M.; Giacobbi, F.; Bambi, F.; et al. Mesenchymal progenitors aging highlights a miR-196 switch targeting HOXB7 as master regulator of proliferation and osteogenesis. Stem Cells 2015, 33, 939-950. [CrossRef]

55. Selleri, L.; Zappavigna, V.; Ferretti, E. ‘Building a perfect body': Control of vertebrate organogenesis by PBX-dependent regulatory networks. Genes Dev. 2019, 33, 258-275. [CrossRef]

56. Moens, C.B.; Selleri, L. Hox cofactors in vertebrate development. Dev. Biol. 2006, 291, 193-206. [CrossRef] [PubMed]

57. Couly, G.; Grapin-Botton, A.; Coltey, P.; Ruhin, B.; Le Douarin, N.M. Determination of the identity of the derivatives of the cephalic neural crest: Incompatibility between Hox gene expression and lower jaw development. Development 1998, 125, 3445-3459. [PubMed]

58. Creuzet, S.; Couly, G.; Vincent, C.; Le Douarin, N.M. Negative effect of Hox gene expression on the development of the neural crest-derived facial skeleton. Development 2002, 129, 4301-4313.

59. Couly, G.; Creuzet, S.; Bennaceur, S.; Vincent, C.; Le Douarin, N.M. Interactions between Hox-negative cephalic neural crest cells and the foregut endoderm in patterning the facial skeleton in the vertebrate head. Development 2002, 129, 1061-1073.

60. Jaffe, A.B.; Hall, A. Rho GTPases: Biochemistry and biology. Ann. Rev. Cell Dev. Biol. 2005, 21, 247-269. [CrossRef] [PubMed]

61. Wiegering, A.; Ruther, U.; Gerhardt, C. The ciliary protein Rpgrip11 in development and disease. Dev. Biol. 2018, 442, 60-68. [CrossRef]

62. Lin, H.; Guo, S.; Dutcher, S.K. RPGRIP1L helps to establish the ciliary gate for entry of proteins. J. Cell Sci. 2018, 131. [CrossRef] [PubMed]

63. Gerhardt, C.; Lier, J.M.; Burmuhl, S.; Struchtrup, A.; Deutschmann, K.; Vetter, M.; Leu, T.; Reeg, S.; Grune, T.; Ruther, U. The transition zone protein Rpgrip1l regulates proteasomal activity at the primary cilium. J. Cell Biol. 2015, 210, 115-133. [CrossRef]

64. Feng, J.S.; Sun, J.D.; Wang, X.D.; Fu, C.H.; Gan, L.L.; Ma, R. MicroRNA-204-5p targets SOX11 to regulate the inflammatory response in spinal cord injury. Eur. Rev. Med. Pharmacol. Sci. 2019, 23, 4089-4096. [CrossRef]

65. Liu, N.; Zhang, Z.; Li, L.; Shen, X.; Sun, B.; Wang, R.; Zhong, H.; Shi, Q.; Wei, L.; Zhang, Y.; et al. MicroRNA-181 regulates the development of Ossification of Posterior longitudinal ligament via Epigenetic Modulation by targeting PBX1. Theranostics 2020, 10, 7492-7509. [CrossRef] [PubMed]

66. Wu, B.; Li, J.; Wang, H.; Wu, Q.; Liu, H. MiR-132-3p serves as a tumor suppressor in mantle cell lymphoma via directly targeting SOX11. Naunyn-Schmiedeberg's Arch. Pharmacol. 2020, 393, 2197-2208. [CrossRef] [PubMed]

67. Liu, J.; Wang, L.; Li, J.; Xu, Y. Upregulation of microRNA-650 by PBX1 is correlated with the development of Helicobacter pylori-associated gastric carcinoma. Neoplasma 2020. [CrossRef] [PubMed]

68. Hu, X.; Chen, Z.; Mao, X.; Tang, S. Effects of phenytoin and Echinacea purpurea extract on proliferation and apoptosis of mouse embryonic palatal mesenchymal cells. J. Cell. Biochem. 2011, 112, 1311-1317. [CrossRef]

69. Pezzetti, F.; Carinci, F.; Palmieri, A.; Vizzotto, L.; Moscheni, C.; Vertemati, M.; Calastrini, C.; Pellati, A.; Stabellini, G. Diphenylhydantoin plays a role in gene expression related to cytoskeleton and protein adhesion in human normal palate fibroblasts. Pathology 2009, 41, 261-268. [CrossRef]

70. Bosi, G.; Evangelisti, R.; Valeno, V.; Carinci, F.; Pezzetti, F.; Calastrini, C.; Bodo, M.; Carinci, P. Diphenylhydantoin affects glycosaminoglycans and collagen production by human fibroblasts from cleft palate patients. J. Dent. Res. 1998, 77, $1613-1621$. [CrossRef] [PubMed] 